\title{
Correction to: Corporate governance and employee treatment: Evidence from takeover defenses
}

\author{
Omer Unsal ${ }^{1} \cdot$ Blake Rayfield $^{2}$ \\ Published online: 26 June 2019 \\ (C) Academy of Economics and Finance 2019
}

\begin{abstract}
This study investigates if antitakeover provisions are a value-enhancing indicator of corporate governance by estimating the effect of takeover susceptibility to labor litigations. Using a unique hand-collected dataset of employee lawsuits, we find a positive relationship between employee litigation and takeover protection. We document that employee lawsuits increase a firm's susceptibility to a hostile takeover. In addition, we document that higher costs of litigation, measured by fees and case duration, increase the firms' suitability to takeover. Our results indicate that takeover protections may decrease corporate attention to employees. This effect may be because entrenched managers may avoid long-term investment in stakeholders and enjoy "the quiet life" following the reduced threat of a hostile takeover.
\end{abstract}

Keywords Employee lawsuits $\cdot$ Hostile takeovers $\cdot$ Corporate governance $\cdot$ Managerial entrenchment

JEL codes $\mathrm{K} 31 \cdot \mathrm{K} 41 \cdot \mathrm{G} 30 \cdot \mathrm{G} 34$

\section{Correction to: J Econ Finan \\ https://doi.org/10.1007/s12197-019-09478-4}

The previous version of the article was uploaded incorrectly. The version below is the correct version of the article.

The online version of the original article can be found at https://doi.org/10.1007/s12197-019-09478-4

Omer Unsal

unsalo@merrimack.edu

Blake Rayfield

blake.rayfield@indstate.edu

1 Girard School of Business, Merrimack College, 315 Turnpike St, North Andover, MA 01845, USA

2 Scott College of Business, Indiana State University, Federal Hall 30 N. 7th St, Terre Haute, IN 47809, USA 


\section{Introduction}

The way in which a firm treats its employees can have a lasting impact on the firm. However, stakeholder and agency theory generally disagree on the required importance needed to maintain a positive working environment. The stakeholder theory of Freeman (1983) suggests that a firms' involvement in non-investing stakeholders is a value-enhancing activity. This view is supported by literature, such as Bae et al. (2011) who show that friendly workplaces on average have lower debt ratios among other benefits. In contrast, the agency theory Jensen and Meckling (1976) posits that commitment to stakeholders is a value-destroying activity, due to a managers' tendency to overinvest and waste the firm's resources to gain benefit at the expense of shareholders (Barnea and Rubin 2010). In this study, we examine the relationship between the likelihood of a hostile takeover and employee treatment. Specifically, this study investigates the firm's relationship with employees by examining employee lawsuits. We argue that as managers become entrenched through antitakeover provisions, they shift their attention away from employee treatment which increases the probability of a takeover.

To test the relationship between employee relations and managerial entrenchment, we use a unique hand-collected dataset of employee litigations (e.g., benefits, retirement, retaliation, race, sex, disability, age, national origin, religion, color). Employee litigations have evolved into a significant threat against US corporations; employee lawsuits are the most frequent allegations against corporations. There is a $12 \%$ chance that a U.S.-based small or medium-size enterprise will be the subject of an employee lawsuit. ${ }^{1}$ In addition, the median judgment is approximately $\$ 200,000$, and one in four cases results in a judgment of $\$ 500,000$ or more ${ }^{2}$ or can take 318 days to settle on average. ${ }^{3}$ Lawsuits result in direct costs (e.g., court fees, settlements, penalties, and attorney fees) and indirect costs (e.g., loss of motivation, loss of firm reputation, and loss of workforce) that can hurt a firm's value overtime.

In this study, we investigate how shareholder control over governance practices affects the way the resources of the firm are allocated. Briefly, we ask if management is more inclined to satisfy the interests of non-shareholding stakeholders when freed from possible short-term takeover threats. We suggest that decreasing the threat of takeovers can result in an offsetting effect on managerial practices. When antitakeover provisions pass, we expect greater slack in managerial response to firm-level operations due to a drop in the possibility of being punished through a takeover (Bertrand and Mullainathan 2003). Our primary hypothesis is that as employee relations deteriorate the likelihood of a firm becoming the target of a takeover is increased. To show this empirically, we exploit antitakeover provisions as an exogenous shock to firm performance

\footnotetext{
${ }^{1}$ Hiscox: Employee Charge Trends Across the United States: http://www.hiscox.com/shared-documents/The2015-Hiscox-Guide-to-Employee-Lawsuits-Employee-charge-trends-across-the-United-States.pdf

${ }^{2}$ The 2017 Hiscox Guide to Employee Lawsuits: https://www.hiscox.com/documents/2017-Hiscox-Guide-toEmployee-Lawsuits.pdf

${ }^{3}$ Employee Lawsuits: Costs, types of suits and 2017 employment law issues in review: https://www.theeap. com/regulatory/employee-lawsuits-costs-types-suits-2017-employment-law-issues-review
} 
in the United States between 2000 and 2014. In addition, we measure employee relations using employment litigations. These lawsuits are less likely to be affected by endogeneity concerns since individual firms do not choose them. Kacperczyk (2009) suggests that stronger antitakeover protections lower the corporate attention to stakeholders due to lowered market discipline for opportunistic managers (Jensen and Ruback 1983) who engage in self-serving activities (Karpoff and Malatesta 1989; Mahoney and Mahoney 1993; Pound 1987) and reduce the amount of resources that benefit the non-shareholding stakeholders (Jensen 2002).

Our study contributes to the literature on stakeholders, managerial entrenchment, and firm value in two ways. First, we contribute to the literature on the level of employee relations beyond the corporate social responsibility (CSR) literature, by providing empirical support of legal allegations, direct and indirect costs of lawsuits, and case characteristics. Second, previous literature documents how antitakeover provisions influence firm value (Chang and Zhang 2015; Gompers et al. 2003); this study shows how channels do so.

Utilizing data from employee litigations between 2000 and 2014, we document that an increasing number of employee litigation increases a firm's susceptibility to a hostile takeover. Our results suggest a disadvantageous aspect of protection from takeovers, where defense provisions can impose ex-ante costs on incentives for stakeholders (Shleifer and Summers 1988).

We then examine how case characteristics can influence a firms susceptibility to takeover. We perform analysis using different case characteristics such as litigation cost as well as case type. We find the results to remain consistent across types of cases. The more cases a firm experience, the higher its takeover likelihood. Next, we use different proxies for employee litigations. We hand collect individual discrimination charges along with settlement and attorney fees. In addition, we collect workplace safety investigations and inspections, benefit- and wage-related complaints to measure how takeover defenses influence overall employee relations. We find that increase litigation increase the susceptibility to a hostile takeover.

Our study makes several significant contributions to the takeover literature. First and foremost, we extend prior research on the effects of takeover provisions on stakeholder relations by examining litigations and legal allegations beyond CSR scores. Second, our study introduces a unique, hand-collected dataset of employee lawsuits, charges, settlement fees, attorney fees, legal fees, complaints, inspections, and disputes. Third, we contribute to the fierce debate on the costs and benefits of employee relations. And fourth, our work highlights the potential implications of changes in corporate governance mechanism and managerial entrenchment on labor relations. Our evidence may support the agency view, where managers are forced to cut back on benefits for stakeholders (e.g., employees) when governance is more effective. To our knowledge, this is the first research to focus directly on takeover susceptibility and employee litigations. We aim to fill this gap in the literature by empirically testing how takeover provisions can impose ex-ante costs on firms' stakeholders.

This paper proceeds as follows: We provide a summary of existing literature on takeover defenses as well as hypothesis development in Section 2. In Section 4 we present the data and methodology used in this study. In Section 4, we discuss our findings, and we conclude our work in Section 5. 


\section{Literature Review \& Hypothesis Development}

\subsection{Firm takeover and employee treatment}

In this section, we examine the main findings in takeover literature and compare our findings to previous studies. The takeover literature consists of mixed findings when it comes to firm performance and governance practices. Takeover provisions have been positively linked to operating performance directly, such as a firm's ability to attract new customers (Cen et al. 2015) and increased innovation outcomes (Manso 2011; Chemmanur and Tian 2017). In addition, takeover provision studies have also focused on allowing higher levels of voluntary disclosures (Zhao et al. 2013); shielding management from performance (Duru et al. 2013), helping managers to pursue long-term goals (Stein 1988); reducing the likelihood of harmful earnings management (Bhojraj et al. 2017) and stock price crash risk (Bhargava et al. 2017); lowering firm leverage (Garvey and Hanka 1999); decreasing bond yields and increasing bond values (Francis et al. 2010). Moreover, antitakeover provisions are positively related to firms' trading at a premium (Daines 2001), and have been found to lower information asymmetry (Armstrong et al. 2012). Driving such provisions may be industry-specific conditions (Cremers et al. 2008). The main suggestion is that takeover provisions lower the likelihood of a takeover threat in the short run, allowing managers to focus on creating long-term value (reduced managerial myopia).

On the other hand, sizable literature finds adverse effects of takeover provisions on firm value. As a corporate control mechanism, takeover provisions lower firm value if CSR is present (Surroca and Tribó 2009), as well as reducing overall CSR score for responsible firms (Chintrakarn et al. 2016; Sheikh 2018). Takeover provisions that make it difficult to replace current management are found to lower innovation (Johnson and Rao 1997; Long and Ravenscraft 1993). Antitakeover defenses may also lower firms' accounting performance, Tobin's Q, and investment rates (Gompers et al. 2003; Bertrand and Mullainathan 2003; Bebchuk and Cohen 2005; Bebchuk et al. 2008; Cohen and Wang 2013; Szewczyk and Tsetsekos 1992; Pugh and Jahera 1990; Karpoff and Malatesta 1989; Hackl and Testani 1988; Moore et al. 2017). This line of research suggests that antitakeover defenses may increase managerial entrenchment, as managers can avoid long-term investment and enjoy "the quiet life" following the reduced possibility of takeover threats. For example, Cheng et al. (2004) find that managers lower their stock-holding when states pass antitakeover laws because they are assured of control over the firm while holding fewer risky shares.

Our study is similar to those of Sheikh (2018) and Kacperczyk (2009), who examined the impact of takeover provisions on CSR. However, we differ from those studies in two ways. First, we examine how takeover provisions affect the relationship with the firm's employees. We measure the relationship between employees and a firms likelihood of takeover using a unique hand-collected dataset of litigations, complaints, investigations, and other disputes filed by workers each year at the firm level, with settlements and other legal fees. 
Therefore, our study shows not only the impact of poor employee relations on the susceptibility to a hostile takeover but also the severity of those allegations. Second, previous studies use CSR scores from KLD ratings. However, CSR has different dimensions, such as environmental, social, economic, stakeholder, voluntariness. Therefore, antitakeover provisions can have heterogeneous effects on the unique dimensions of CSR. Kacperczyk (2009) finds takeover protections influence corporate attention to community and environment, but have no impact on employees, minorities, and customer scores. Our study shows that when measuring employee relations, specifically by employment litigation, we find an empirical relationship between corporate governance practices and a firm's relations with its workers.

\subsection{Hypothesis development}

According to Coff (1997), employees are the most valuable asset of a firm, and employee satisfaction contributes to better corporate performance. Two primary theories explain how firms interact with their employees and stakeholders. First, shareholder theory suggests that managers should focus on maximizing shareholder wealth in order to maximize the welfare of all stakeholders. For example, corporate social responsibility (CSR) can be considered an agency problem (Freidman 1970). Overinvestment in CSR is related to managers exploiting corporate resources at the expense of shareholders (Barnea and Rubin 2010). In contrast, the stakeholder theory of Freeman (1983) and Jensen (2002) suggests that maximizing stakeholder welfare involves management serving all stakeholders, without prioritizing the interests of shareholders over others. From this perspective, CSR is a long-term strategic investment that balances the interests of both shareholders (investing stakeholders) and stakeholders (non-investing stakeholders).

Both shareholder and stakeholder suggest differing opinions regarding the relationship between employees and the probability of a firm takeover. First, the threat of a takeover can influence a managers' decision-making process by increasing career concerns. If managers fail to maximize shareholder wealth, a drop in stock price will facilitate a hostile takeover which may replace underperforming management (Manne 1965). If antitakeover provisions alleviate the career concerns of management, the takeover mechanism that removes underperforming management is removed, which will trigger managerial self-dealing. Therefore, to maximize stakeholder wealth, managers should attend to the interest of shareholders, since the market reacts adversely to managerial decisions that deviate from the maximization of shareholder value. Relieving managers from takeover threats, we would expect that takeover protection would lead to a decline in corporate attention to both shareholders as well as stakeholders.

Second, the ability to utilize substantial firm resources increases when incumbent managers become entrenched. Collins and Huang (2011) show the relationship between managerial entrenchment and the costs of equity capital are associated, and antitakeover provisions can further entrench managers, which may shield managers from disciplinary actions (DeAngelo and Rice 1983; Jensen and Ruback 1983). In that case, it is predictable that managerial entrenchment encourages managers to avoid long-term investments and enjoy "the quiet life." Less pressure on managers may be the reason that antitakeover defenses lower subsequent long-term investments (Mahoney et al. 
1997; Gompers et al. 2003; Bebchuk et al. 2008; Cremers and Ferrell 2009). Because antitakeover protection is related to managerial entrenchment, we exploit a natural experiment to show that antitakeover provisions can enhance value-destroying activities such as employee litigations. We argue that entrenched managers have no incentives to invest in employee relations, due to the reduced possibility of a takeover threat. Instead, they allocate a firms' resources to other short-term investments as a response to their incentives. In that case, we expect;

Hypothesis 1: All things being equal, a decrease in employee relations as measured by employment litigation leads to a higher probability of a takeover.

$$
\text { Takeover Index }=\beta_{0}+\beta_{1} \text { Litigation }+\sum \beta_{\mathrm{s}} \text { Controls }
$$

We examine the relationship between susceptibility to a hostile takeover and employee relationships by testing $\mathrm{H} 1$. In our model, litigation refers to the log transformation of the total number of lawsuits filed by employees each year at the firm level. For robustness, we employ other proxies for employee lawsuits, such as health and safety inspections, wage-related complaints, wage-related penalties, discrimination charges, and settlement and attorney fees.

\subsection{Takeover index}

To measure the firms' susceptibility to takeover, we employee the index of Cain et al. (2017). ${ }^{4}$ The index measures the probability of a hostile takeover using the passage of 12 different types of state takeover laws, one federal statue, and three state standards of review. ${ }^{5}$ A higher takeover index indicates a higher probability of being taken over and, thus, stronger lower protections for corporate governance (Bertrand and Mullainathan 2003). We use Takeover Index as a proxy between firm-level and external governance mechanisms to measure the intensity of corporate governance. The index captures the notions that firms are pressured to adopt strong corporate governance if they are exposed to hostile takeover (as indicated by higher takeover index). Liu (2016) document that the Takeover Index has explanatory power in corporate misconduct. The same index is also found to explain corporate innovation (Atanassov and Liu 2014), corporate tax avoidance (Chen et al. 2016), stock price crash risk (Al Mamun et al. 2017), cash holding (Duong et al. 2017), CEO turnover (Schmid et al. 2016), and investors' reactions to the announcement of seasoned equity offerings (SEOs) (Sheikhbahaei et al. 2018).

\footnotetext{
${ }^{4}$ Data on the takeover index of Cain et al. (2017) can be found at: http://pages.uoregon.edu/smckeon/

5 The index includes first generation statues, business combination, fair price, control share acquisition, control share cash-out, poison pill, expanded constituency, disgorgement, anti-greenmail, golden parachute restriction, tin parachute blessing, and assumption of labor contracts laws. The federal statue is the Williams Act in 1968. The three standards of review are based on court decisions including Revlon, Inc. v. MacAndrews \& Forbes Holdings, Unocal v. Mesa Petroleum, and Blasius Industries v. Atlas Corp.
} 


\section{Data}

We use the S\&P Capital IQ database to identify the publicly traded firms between 2000 and 2014. We hand collect data from the National Labor Relations Board database on more than 31,000 employee litigations that received an initial court hearing between 2000 and 2014. The NLRB database includes cases filed for coercive actions, coercive statements, harassment, bad faith bargaining, changes in working conditions, discharge, discipline, change in working contract, and refusal to furnish information. In addition to employee litigations, we also hand-collect data on other employee allegations from the U.S. Department of Labor. These databases include the Occupational Safety and Health Administration (OSHA) enforcement data, Wage and Hour Compliance Action Data, and Employee Benefits and Security Enforcement Data. In addition, we gather lawsuit announcements and news releases in discrimination cases with settlement amount and attorney fees for S\&P Capital IQ.

Table 1 documents the summary statistics of the variables used in our study. Panel A represents the summary statistics for employee level litigations, other disputes, and cost of litigation. Panel B exhibits the summary statistics of the control variables used in this study. Detailed definitions of the variables are available in Appendix 1.

Since our dependent variable is the takeover index, our control variables include a rich set of firm-level variables that are known to affect the likelihood of a firm hostile takeover. We add control variables to eliminate omitted variable bias. Our control variables include firm-specific variables, CEO specific variables, and labor-related variables. Firm-specific variables are log transformation of total assets, log transformation of number of employees, ROA, book-to-market ratios, book leverage, log transformation of firm age, capital liquidity, cash holding, capital expenditures, and Herfindahl index. CEO-specific variables are log transformation of CEO compensation and $\log$ transformation of CEO age. Labor-related control variables are pension expenses, personal intensity, property-plant-equipment, state-level unionization rate, percentage of unionization at industry level, and union membership growth at industry level. In our regressions, we run industry and year, year and state (location), year and firm fixed effects to eliminate any unobserved heterogeneity. In addition, we cluster all standard errors at the firm level.

\section{Empirical results}

\subsection{Univariate analysis}

In Table 2, we run two sets of univariate analysis. In the first set of tests, we divide our sample based on the susceptibility to hostile takeovers. Above Index, is a sample of firms with a takeover index greater than mean susceptibility to hostile takeovers. Below Index, is a sample for firms that score lower than mean susceptibility to hostile takeovers.

In Panel B, we create a sample based on firms' incorporation state. 'Restrictive' means the firm is located in a state that has passed restrictive takeover provisions (Francis et al. 2010). The unrestrictive sample is for firms incorporated in states subject to no state-level takeover defenses. 
Table 1 Summary statistics

\begin{tabular}{|c|c|c|c|c|}
\hline Variables & Mean & Std.Dev & Min & Max \\
\hline \multicolumn{5}{|l|}{ Panel A. Employee Disputes } \\
\hline Num. of Total Case & 0.91 & 3.45 & 0.00 & 224.00 \\
\hline Num. of Discrimination Case & 0.11 & 2.13 & 0.00 & 16.00 \\
\hline Num. of Total Dispute & 12.01 & 31.09 & 0.00 & 322.00 \\
\hline Cost of Litigation & $41,011.00$ & $1,345,901.00$ & 0.00 & $181,000,000.00$ \\
\hline \multicolumn{5}{|l|}{ Panel B. Control Variables } \\
\hline Takeover Index & 0.15 & 0.09 & 0.01 & 0.82 \\
\hline $\log ($ Asset $)$ & 7.65 & 1.62 & 4.98 & 10.74 \\
\hline Log(Num. Emp) & 1.87 & 1.20 & 0.22 & 4.30 \\
\hline ROA & 0.04 & 0.07 & -0.14 & 0.16 \\
\hline Book-to-Market & 0.01 & 0.01 & 0.00 & 0.05 \\
\hline Book Leverage & 0.22 & 0.18 & 0.00 & 0.60 \\
\hline Log(CEO Age $)$ & 4.03 & 0.12 & 3.81 & 4.23 \\
\hline Log(CEO Compensation) & 8.03 & 0.98 & 6.22 & 9.74 \\
\hline Log(Firm Age) & 3.11 & 0.64 & 1.95 & 4.08 \\
\hline Capital Liquidity & 4.20 & 1.76 & 2.39 & 8.23 \\
\hline Cash Holding & 0.13 & 0.13 & 0.00 & 0.43 \\
\hline CAPEX & 4.29 & 3.93 & 0.05 & 14.74 \\
\hline Herfindahl Index & 0.05 & 0.03 & 0.02 & 0.14 \\
\hline Pension Expenses & 0.01 & 0.01 & 0.00 & 0.03 \\
\hline Personal Intensity & 0.06 & 0.01 & 0.00 & 0.11 \\
\hline Property, Plant, Equip. & 0.12 & 0.01 & 0.00 & 0.78 \\
\hline State Unionization & 5.88 & 4.45 & 0.80 & 17.30 \\
\hline$\%$ Industry unionization & 6.57 & 4.58 & 1.20 & 18.00 \\
\hline Union memb. Growth & 0.03 & 0.71 & -1.60 & 1.40 \\
\hline
\end{tabular}

Table 1 exhibits the summary statistics at the firm level. Panel A represents the employee lawsuit characteristics at the firm level. Panel B represents the firms level control variables used in the study. Detailed definitions of variables are reported in the appendix

Table 2 documents the univariate relationship between the takeover index and control variables used in the study. We compare mean scores and report the differences along with t-stats. Our results document that firms with susceptibility to hostile takeovers greater than the sample mean to have a greater number of cases filed against them compared to firms with a lower takeover index. Similarly, we find a higher number of employee disputes and more discrimination cases filed for firms with takeover protection. Our results remain the same when we compare the cost of litigation (e.g., settlement fees, attorney fees, or other legal fees) among the two samples.

In Panel B, we compare the sample of firms based on their incorporation states and the takeover measures passed in those states. We find that firms incorporated in states with high takeover protection suffer from a greater number of litigations. When firms are incorporated in states with more takeover restrictions, our results show that the year 
Table 2 Anti-takeover protection and employee lawsuits: univariate analysis

\begin{tabular}{|c|c|c|c|c|}
\hline Panel A. & Above Index & Below Index & Difference & T-Stat \\
\hline Total Case & 1.29 & 0.47 & 0.82 & $10.84 * * *$ \\
\hline Discrimination Case & 2.33 & 0.02 & 2.31 & $9.98 * * *$ \\
\hline Total Dispute & 5.56 & 1.44 & 4.12 & $5.67 * * *$ \\
\hline Cost of Litigation & $\$ 988,032.00$ & $\$ 97,221.00$ & $\$ 890,811.00$ & $14.56 * * *$ \\
\hline $\log ($ Asset $)$ & 8.18 & 6.77 & 1.41 & $6.55 * * *$ \\
\hline Log(Num. Emp) & 2.07 & 1.60 & 0.48 & $9.67 * * *$ \\
\hline $\mathrm{ROA}$ & 0.03 & 0.01 & 0.02 & $3.50 * * *$ \\
\hline Book-to-Market & 0.33 & 0.48 & -0.15 & {$[-1.45]$} \\
\hline Book Leverage & 0.25 & 0.23 & 0.02 & $2.07 * *$ \\
\hline Log(CEO Age $)$ & 4.04 & 4.00 & 0.04 & $13.47 * * *$ \\
\hline Log(CEO Compensation) & 8.13 & 7.79 & 0.34 & $11.44 * * *$ \\
\hline Log(Firm Age $)$ & 3.40 & 2.59 & 0.81 & $5.65 * * *$ \\
\hline Capital Liquidity & 4.15 & 4.29 & -0.14 & {$[-6.45]^{* * *}$} \\
\hline Cash Holding & 0.11 & 0.17 & -0.06 & {$[-13.11] * * *$} \\
\hline CAPEX & 4.24 & 5.36 & -1.12 & {$[-16.55]^{* * *}$} \\
\hline Herfindahl Index & 0.06 & 0.06 & 0.00 & {$[-2.08]^{* * *}$} \\
\hline Pension Expenses & 0.20 & 0.02 & 0.18 & 1.09 \\
\hline Personal Intensity & 0.01 & 0.11 & -0.10 & {$[-7.33] * * *$} \\
\hline Property, Plant, Equip. & 0.33 & 0.12 & 0.21 & $6.55^{* * *}$ \\
\hline State Unionization & 6.84 & 5.73 & 1.11 & $14.12 * * *$ \\
\hline$\%$ Industry unionization & 7.60 & 6.45 & 1.15 & $6.88 * * *$ \\
\hline Union memb. Growth & 0.03 & 0.01 & 0.03 & $1.69 *$ \\
\hline Panel B. & Restrictive & Unrestrictive & Difference & T-Stat \\
\hline Total Case & 2.12 & 1.03 & 1.09 & $4.03 * * *$ \\
\hline Year 2000 - Total Case & 1.44 & 0.48 & 0.97 & $3.59 * * *$ \\
\hline Year 2001 - Total Case & 1.70 & 0.64 & 1.06 & $2.98 * * *$ \\
\hline Year 2002 - Total Case & 1.78 & 0.72 & 1.06 & $2.90 * * *$ \\
\hline Year 2003 - Total Case & 1.90 & 0.74 & 1.16 & $3.15^{* * *}$ \\
\hline Year 2004 - Total Case & 1.94 & 0.83 & 1.11 & $3.91 * * *$ \\
\hline Year 2005 - Total Case & 1.59 & 0.68 & 0.91 & $5.82 * * *$ \\
\hline Year 2006 - Total Case & 1.32 & 0.60 & 0.72 & $4.31 * * *$ \\
\hline Year 2007 - Total Case & 1.09 & 0.48 & 0.61 & $3.52 * * *$ \\
\hline Year 2008 - Total Case & 1.27 & 0.41 & 0.86 & $3.29 * * *$ \\
\hline Year 2009 - Total Case & 1.01 & 0.51 & 0.51 & $2.12 * *$ \\
\hline Year 2010 - Total Case & 0.30 & 0.14 & 0.16 & $3.73 * * *$ \\
\hline Year 2011 - Total Case & 1.30 & 0.65 & 0.65 & $3.05 * * *$ \\
\hline Year 2012 - Total Case & 1.01 & 0.65 & 0.37 & $4.09 * * *$ \\
\hline Year 2013 - Total Case & 1.10 & 0.64 & 0.46 & $3.45 * * *$ \\
\hline Year 2014 - Total Case & 1.23 & 0.56 & 0.67 & $2.07 * * *$ \\
\hline
\end{tabular}

Table 2 documents univariate analysis among variables used in this study. In Panel A, we divide our sample as Above Index and Below Index based on the mean value of Takeover Index. In Panel B, we divide our sample as Restrictive and Unrestrictive states based on Francis et al. (2010). Detailed definitions of variables are reported in the appendix. *, **, and $* * *$ indicate statistical significance at the $10 \%, 5 \%$, and $1 \%$ levels, respectively 
over year number of litigations is increased. We also plot the total number of cases between restrictive and unrestrictive states in Fig. 1 to visually document the trend in employee litigations.

Figure 1 displays the total number of employee lawsuits filed each year for our sample period across incorporation state classification. We plot more than 31,000 cases filed each year. We show that, over time, the total number of employee lawsuits for firms incorporated in restrictive law states is greater than the number of employee lawsuits filed for firms incorporated in states with more unrestrictive laws. The results of Table 2 and Fig. 1 provide primary visual evidence for our argument. More takeover protections lead to a greater chance of litigation.

\subsection{Multivariate analysis}

In this section, we run several multivariate tests to examine the relationship between a takeover index and employee litigations. In Table 3, we use the log transformation of the total number of employee lawsuits as an explanatory variable. We regress the takeover index on the total log number of litigations while controlling for several effects.

Table 3 represents the relation between antitakeover provisions and employee relations. In column (1) and (2), we run industry and year fixed effects. In column (3) and (4), we run firm and year fixed effects to eliminate any unobserved heterogeneity. Our results document that the number of employee litigations is positively and significantly related to the likelihood of experiencing a firm takeover. We find that a higher number of litigations filed by employees increases a firms' susceptibility to hostile takeovers. Our primary results begin to show how important employee treatment is to both managers and takeovers. As management becomes more entrenched, they may tend to reduce investment in stakeholders (in this case, employees). As

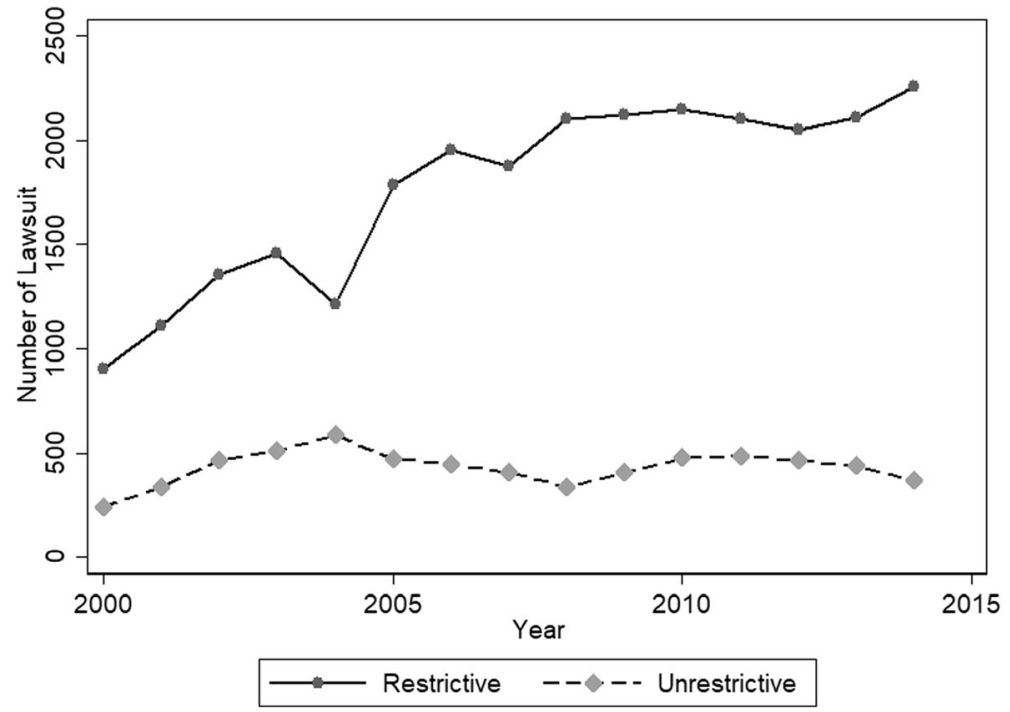

Fig. 1 Employee lawsuits over time and across state of incorporation groups 
Table 3 Employee lawsuits and anti-takeover protection

Panel A.

Dependent Variable

Takeover Indext+1 Takeover Indext+2 Takeover Indext+1 Takeover Indext+2

Sample

(1) (2)

$\log ($ Litigation $)$

Log(Asset)

Log(Num. Emp)

ROA

Book-to-Market

0.334

$[0.001]^{* * *}$

0.033

$[0.001]^{* * *}$

0.218

$[0.001]^{* * *}$

$-0.060$

$[0.018]^{* *}$

0.001

$[0.001]^{* * *}$

Book Leverage

0.001

[0.840]

Log(CEO Age $)$

$-0.003$

[0.917]

Log(CEO Compensation) $\quad-0.008$

$[0.069]^{*}$

Log(Firm Age $)$

$-0.017$

[0.213]

Capital Liquidity

0.016

$[0.001]^{* * *}$

Cash Holding

0.100

$[0.001]^{* * * *}$

CAPEX

Herfindahl Index

$-0.003$

$[0.001]^{* * * *}$

Pension Expenses

$-0.516$

$[0.023]^{* *}$

0.032

$[0.014]^{* *}$

Personal Intensity

$-2.399$

$[0.001]^{* * *}$

Property, Plant, Equip. $\quad 4.090$

$[0.001]^{* * * *}$

State Unionization

0.006

[0.741]

$\%$ Industry unionization

$-0.008$

[0.669]

Union memb. Growth

$-0.002$

[0.953]
0.886

$[0.001]^{* * * *}$

0.036

$[0.001]^{* * * *}$

0.219

$[0.001]^{* * *}$

$-0.108$

$[0.001]^{* * *}$

0.001

$[0.001]^{* * *}$

$-0.001$

[0.919]

0.013

[0.662]

$-0.009$

[0.039]**

$-0.027$

[0.047]**

0.020

$[0.001]^{* * *}$

0.110

$[0.001]^{* * * *}$

$-0.003$

$[0.001]^{* * *}$

$-0.712$

$[0.001]^{* * *}$

0.030

$[0.021]^{* *}$

$-2.315$

[0.001]***

3.537

$[0.001]^{* * *}$

$-0.001$

[0.974]

0.001

[0.943]

0.002

[0.650]
(3)

0.122

[0.001]***

0.034

$[0.001]^{* * * *}$

0.218

$[0.001]^{* * * *}$

$-0.113$

$[0.001]^{* * * *}$

0.001

$[0.001]^{* * * *}$

0.050

$[0.023]^{* *}$

0.023

[0.458]

$-0.011$

$[0.020]^{* *}$

$-0.031$

$[0.024]^{* *}$

0.035

$[0.001]^{* * *}$

0.103

$[0.001]^{* * * *}$

$-0.004$

$[0.001]^{* * * *}$

$-0.718$

$[0.001] * * *$

0.024

[0.047]**

$-2.257$

$[0.001]^{* * * *}$

3.883

$[0.001]^{* * * *}$

0.010

[0.618]

$-0.007$

[0.725]

$-0.003$

[0.516]
(4)

0.688

$[0.017]^{* *}$

0.002

$[0.001]^{* * * *}$

0.185

$[0.001]^{* * * *}$

$-0.006$

[0.541]

0.001

[0.532]

0.001

[0.921]

0.027

[0.385]

$-0.006$

[0.151]

$-0.035$

[0.031]**

0.002

[0.193]

$-0.045$

[0.251]

0.001

[0.289]

$-0.206$

[0.120]

0.011

[0.097]*

$-1.553$

$[0.001]^{* * * *}$

0.782

$[0.001]^{* * * *}$

0.047

$[0.001]^{* * * *}$

$-0.036$

$[0.001]^{* * * *}$

$-0.013$

$[0.001]^{* * * *}$ 
Table 3 (continued)

Panel A.

\begin{tabular}{lllll}
\hline Industry/Year & YES & YES & NO & NO \\
Firm/Year & NO & NO & YES & YES \\
$\mathrm{N}$ & 18,935 & 18,169 & 18,935 & 18,169 \\
$\mathrm{R}^{2}$ & $28 \%$ & $16 \%$ & $17 \%$ & $14 \%$ \\
\hline
\end{tabular}

Table 3 reports the multivariate regression results between employee lawsuits and Takeover Index controlling for firm-level variables. From column (1) to column (4), our dependent variable takeover index. In column (1), and (2), we run industry and year fixed effects, but omit the coefficients. In column (3) and (4), we run firm and year fixed effects. Standard errors are clustered at the firm level. Detailed definitions of variables are reported in the appendix. *, **, and *** indicate statistical significance at the $10 \%, 5 \%$, and $1 \%$ levels, respectively

employee relations break down the likelihood of takeover may increase. Thus, Table 3 indicates that investing in employee relations may be a long-term strategic investment. Our results are similar to Sheikh (2018), who documents a negative and significant relationship between takeover provisions and CSR involvement.

\subsection{Severity of litigations and other disputes}

In the previous section, we document that employee lawsuits increase with a firm's susceptibility to a hostile takeover. We use alternative proxies for employee lawsuits and include direct costs of those litigations. In Table 4, we employ a unique hand-collected dataset of discrimination charges and the legal cost of those cases. Our main lawsuit variable, the NLRB database includes work-related allegations and union issues, does not contain discrimination charges. We search the S\&P Capital IQ database for lawsuit announcements and news releases for discrimination-related charges. Discrimination cases are important and bring a unique perspective to our analysis. For example, unfairness and workplace discrimination against workers costs businesses an estimated 64 billion USD every year. ${ }^{6}$ The Equal Employment Opportunity Commission (EEOC) states that 75,000 discrimination charges in the early 2000s rose to more than 91,000 cases by $2016 .^{7}$ In addition, the Equal Employment Opportunity Commission (EEOC) documents that 84,254 discrimination charges were filed in 2017, securing \$398 million for victims and handling over 540,000 calls to its toll-free number and more than 155,000 inquiries in field offices. $^{8}$ Given the significant number and size of discrimination cases, we believe these cases warrent additional tests to examine how takeover provisions affect certain types of litigations.

\footnotetext{
${ }^{6}$ Workplace Discrimination Costs Businesses \$64 Billion Every Year: https://www.huffingtonpost.com/2012 /03/23/workplace-discrimination-costs-businesses-cap_n_1373835.html

${ }^{7} \mathrm{https}$ ://www.eeoc.gov/eeoc/statistics/enforcement/charges.cfm

${ }^{8}$ EEOC Releases Fiscal Year 2017 Enforcement And Litigation Data: https://www.eeoc. gov/eeoc/newsroom/release/1-25-18.cfm
} 
Table 4 Anti-takeover protection and employee lawsuits: discrimination cases

Panel A.

Dependent Variable

$\begin{array}{ccccc}\text { Takeover } & \text { Takeover } & \text { Takeover } & \text { Takeover } & \text { Takeover } \\ \text { Indext+1 } & \text { Indext+2 } & \text { Indext+1 } & \text { Indext+2 } & \text { Indext+1 }\end{array}$

Sample
(1)
(2)
(3)
(4)

(5)

$\begin{array}{lll}\log (\text { Discrimination }) & 0.789 & 0.778 \\ & {[0.001]^{* * *}} & {[0.001]^{* * * *}}\end{array}$

Log(Litigation Cost)

$\begin{array}{ll}0.334 & 0.899 \\ {[0.013]^{* *}} & {[0.021]^{* *}}\end{array}$

Log(Dispute)

$\log$ (Asset)

0.006

0.007

0.040

0.043

0.833

$[0.001]^{* * *}$

$[0.001]^{* * * *}$

$[0.022]^{* *}$

$[0.020]^{* *}$

$[0.011]^{* *}$

Log(Num. Emp)

$[0.001]^{* * * *}$

0.022

0.163

0.165

0.181

ROA

$-0.005$

$[0.001]^{* * * *}$

$[0.001]^{* * * *}$

[0.001]***

$[0.001]^{* * *}$

Book-to-Market

$[0.001]^{* * *}$

$-0.006$

$-0.056$

$-0.063$

.330

0.001

$[0.001]^{* * * *}$

$[0.001]^{* * *}$

[0.013]**

$[0.001]^{* * * *}$

0.001

0.001

0.001

[0.131]

Book Leverage

$-0.001$

$[0.001]^{* * * *}$

$[0.001] * * *$

$[0.001]^{* * * *}$

0.001

Log(CEO Age $)$
Log(CEO
Compensation $)$

[0.309]

$-0.008$

$-0.010$

$-0.046$

$[0.001]^{* * * *}$

\section{$-0.007$}

[0.015]**

[0.228]

[0.174]

$-0.012$

[0.184]

$-0.005$

$-0.116$

$-0.059$

[0.427]

$-0.007$

[0.435]

$[0.037]^{* *}$

[0.326]

0.122

$-0.007$

$-0.043$

$-0.037$

[0.717]

Log(Firm Age)

[0.001]***

$[0.001]^{* * *} *$

[0.011]**

[0.041]**

$-0.167$

$-0.006$

$-0.006$

$-0.048$

$-0.049$

[0.059]*

$[0.013]^{* *}$

[0.022]**

[0.101]

[0.104]

0.014

Capital Liquidity

$-0.001$

0.001

$-0.011$

0.015

[0.945]

$[0.045]^{* *}$

[0.067]*

[0.111]

$[0.045]^{* *}$

0.105

Cash Holding

\subsection{4}

0.065

0.301

0.317

$[0.001]^{* * * *}$

\section{CAPEX}

$[0.001]^{* * * *}$

[0.001]****

[0.001]***

$[0.001]^{* * * *}$

1.697

0.011

0.001

0.003

0.004

$[0.071]^{*}$

[0.001]***

$[0.001]^{* * * *}$

$[0.020]^{* *}$

$[0.021]^{* *}$

0.008

Herfindahl Index

$$
0.053
$$

0.119

0.997

1.515

[0.651]

\section{[0.172]}

$[0.015]^{* *}$

[0.056]*

[0.018]**

0.381

Pension Expenses

$-0.002$

$-0.002$

$[0.001]^{* * *}$

$[0.001]^{* * * *}$

$-0.012$

$-0.017$

[0.845]

Personal Intensity

$-0.285 \quad-0.303$

$[0.020]^{* *}$

$[0.001]^{* * * *}$

0.008

$[0.001]^{* * *}$

$[0.001]^{* * *}$

$-1.717$

$-1.864$

[0.903]

Property, Plant, Equip. $\quad 0.958$

0.968

$[0.001]^{* * * *}$

$[0.001]^{* * * *}$

$-6.230$

[0.490]

$[0.001]^{* * *}$

$[0.001]^{* * * *}$

6.684

7.128

3.731

State Unionization

$-0.002$

0.004

$[0.001]^{* * * *}$

$[0.001]^{* * * *}$

[0.467]

0.004

0.041

0.141 
Table 4 (continued)

Panel A.

\begin{tabular}{llllll}
\hline & {$[0.653]$} & {$[0.305]$} & {$[0.908]$} & {$[0.257]$} & {$[0.181]$} \\
\% Industry & 0.002 & -0.003 & -0.004 & -0.035 & -0.162 \\
unionization & {$[0.636]$} & {$[0.308]$} & {$[0.921]$} & {$[0.295]$} & {$[0.113]$} \\
Union memb. Growth & -0.001 & -0.001 & -0.003 & -0.011 & 0.005 \\
& {$[0.462]$} & {$[0.540]$} & {$[0.677]$} & {$[0.231]$} & {$[0.849]$} \\
Industry/Year & YES & YES & YES & YES & YES \\
$\mathrm{N}$ & 18,935 & 18,169 & 18,935 & 18,169 & 18,935 \\
$\mathrm{R}^{2}$ & $7 \%$ & $7 \%$ & $7 \%$ & $6 \%$ & $6 \%$ \\
\hline
\end{tabular}

Table 4 reports the multivariate regression results between additional employee disputes and Takeover Index controlling for firm-level variables. From column (1) to(5), our dependent variable is takeover index. We run industry and year fixed effects but omit the coefficients. Standard errors are clustered at the firm level. Detailed definitions of variables are reported in the appendix. *,**, and *** indicate statistical significance at the $10 \%$, $5 \%$, and $1 \%$ levels, respectively

In Table 4, we measure how the severity of the allegations affect a firm susceptibility to hostile takeovers. In column (1) and column (2), we use the log transformation of the total number of discrimination cases. Consistent with our expectations, we document the number of discrimination charges filed is positively related to the takeover index. We define litigation costs as the log transformation of the total settlement amount, attorney fees, and other legal fees. The results of column (3) and (4) show that increased litigation costs increase the probability of a takeover. In column (5), our independent variable is the log transformation of the total number of OSHA inspections, wage-related complaints, and benefit-related violations. The coefficient of the relationship remains positive and significant in our regression.

There are two types of costs associated with litigation, direct and indirect. Indirect costs can happen with litigation harms a firm's reputation. Columns (1), (2), and (5) measure the impact of indirect costs. We argue that more discrimination cases and disputes increase the likelihood of a firm to a hostile takeover. The effect of direct costs which are associated with monetary measures and is estimated in columns (3) and (4). We show the more litigation costs, the more likely a firm is to experience a hostile takeover.

To further investigate the relationship between employee litigation and takeover, we calculate the case time-to-resolution. Using the time-to-resolution, we examine whether the duration of a firms case can play a role in the firm's susceptibility of becoming a takeover target. Case duration is calculated as the difference between the case closure date and case opening date measured in days. We run survival analysis to test how the takeover index is related to case duration. If the costs associated with employment litigation increase the firm's susceptibility of becoming a takeover target, then we would expect a longer case duration to have a more significant impact on the likelihood of a takeover. Table 5 documents the results of our analysis.

In Table 5, we run three tests to measure how case duration affects a firm's takeover index. We calculate the case duration for 32,903 individual lawsuits filed between 2000 and 2014. In Column (1) we regress the takeover index on the log transformation of the duration of each case. The results indicated a positive and significant effect of case duration on the likelihood of becoming a takeover target. In columns (2) and (3) we 
Table 5 Anti-takeover protection and employee lawsuits: case duration \& survival analysis

Panel A.

Dependent Variable

Takeover Index

Sample

(2)

0.885

$[0.001]^{* * *}$

One Year

Two Year

$\log ($ Asset)

Log(Num. Emp)

ROA

Book-to-Market

Book Leverage

Log(CEO Age $)$

Log(CEO Compensation)

Log(Firm Age)

Capital Liquidity

Cash Holding

CAPEX

Herfindahl Index

Pension Expenses

Personal Intentisy

Property, Plant, Equip.

State Unionization

$$
\begin{aligned}
& 0.033 \\
& {[0.001]^{* * *}} \\
& 0.056 \\
& {[0.001]^{* * *}} \\
& -0.002 \\
& {[0.001]^{* * *}} \\
& 0.001 \\
& {[0.785]}
\end{aligned}
$$$$
-0.001
$$$$
\text { [0.778] }
$$$$
-0.007
$$$$
[0.001]^{* * * *}
$$$$
-0.007
$$$$
\text { [0.001]*** }
$$$$
-0.006
$$$$
[0.045]^{* *}
$$$$
-0.001
$$$$
\text { [0.778] }
$$

0.064

$[0.001]^{* * * *}$

0.011

$[0.001]^{* * *}$

1.112

$[0.015]^{* *}$

$-0.002$

$[0.001]^{* * * *}$

$-0.112$

$[0.001]^{* * * *}$

0.677

$[0.001]^{* * * *}$

$-0.002$

[0.556]

$$
\begin{aligned}
& 0.177 \\
& {[0.001]^{* * * *}}
\end{aligned}
$$

0.655

$[0.001]^{* * * *}$

0.042

$[0.001]^{* * * *}$

0.021

[0.001] ***

$-0.025$

$[0.001]^{* * * *}$

0.001

[0.977]

$-0.001$

[0.964]

$-0.005$

[0.038]**

$-0.027$

$[0.021]^{* *}$

$-0.006$

[0.013]

$-0.001$

[0.552]

0.059

$[0.001]^{* * * *}$

0.003

$[0.001]^{* * * *}$

1.098

$[0.001]^{* * * *}$

$-0.002$

$[0.001]^{* * * *}$

$-0.117$

$[0.001]^{* * * *}$

0.731

$[0.001]^{* * * *}$

$-0.002$

[0.178] 
Table 5 (continued)

\begin{tabular}{llll} 
Panel A. & & & \\
\hline \% Industry unionization & 0.002 & 0.002 & 0.002 \\
& {$[0.677]$} & {$[0.892]$} & {$[0.522]$} \\
Union memb. Growth & -0.001 & -0.001 & -0.001 \\
& {$[0.577]$} & {$[0.922]$} & {$[0.977]$} \\
CONTROLS & YES & YES & YES \\
Industry/Year & YES & YES & YES \\
$\mathrm{N}$ & 32,903 & 32,903 & 32,903 \\
\hline
\end{tabular}

Table 5 reports the multivariate regression results between case duration and Takeover Index controlling for firm-level variables. We run industry and year fixed effects, and omit the coefficients. Std. errors are clustered at firm level. Detailed definitions of variables are reported in the appendix. *, **, and *** indicate statistical significance at the $10 \%, 5 \%$, and $1 \%$ levels, respectively

create an indicator variable if the case duration is equal between zero and 1 year (1 Year) or greater than 1 year (2 Year). The results confirm the effect detected in column (1) as the case duration grows larger so too does the firms likelihood of becoming a takeover target. Duration, just as the previous measures used in this study, measure both direct and indirect costs associated with litigation. As litigation grows longer, the costs associated with the court grow more significant. In addition, when a case is in the court longer, it can have a heightened effect on the morale of employees as well as the reputation outside the firm.

\subsection{Alternative explanations and endogeneity concerns}

In this section of our study, we run different tests for alternative explanations of the relationship between employee litigations and the takeover index to eliminate endogeneity concerns. In Table 6, we run a natural experiment test to measure what happened to employee lawsuits when the firms' incorporated state passed more antitakeover laws between our sample span of 2000 and 2014. Based on Cain et al. (2017), we identify the following laws passed in states; Texas in $2006=$ Poison Pill Statute + Expanded Constituency; Indiana in 2009 = Mandatory Staggered Board; Kansas in $2003=$ Revlon + Unocal cases; Maine in $2003=$ Poison Pill Statute; Maryland in 2004 = Revlon case; Massachusetts in $2003=$ Unocal case; Michigan in 2001 = Poison Pill Statute + Blasius case; Connecticut in $2000=$ Blasius case. In Table 6, we run a difference-in-differences test and measure how employee lawsuits changed when firms' incorporated states passed antitakeover measures.

Table 6, shows the results of a difference-in-differences test examining exogenous changes at the state level. We create the variable State Located, which is equal to one if the firm is incorporated in any of the states listed above during our sample period. We calculate Post Year, equal to one for the years after states passed additional takeover measures. We then calculate the interaction term of State Located and Post Years. Our results in Panel A of Table 6 document that, following the enactment of antitakeover provisions, firms face increased numbers of litigations. Our results hold for +1 and +2 years following the antitakeover defenses. 
Table 6 Anti-takeover protection and employee lawsuits: difference and difference test

Panel A.

Dependent Variable

$$
\log (\text { Litigation }) \quad \log (\text { Litigation }) t+1 \quad \log (\text { Litigation }) t+2
$$

Sample

$\begin{array}{llll} & (1) & (2) & (3) \\ \text { State Located * Post Year } & 0.031 & 0.048 & 0.055 \\ & {[0.001]^{* * *}} & {[0.045]^{* * *}} & {[0.029]^{* *}} \\ \text { Post Year } & 0.049 & 0.060 & 0.079 \\ & {[0.001]^{* * *}} & {[0.001]^{* * *}} & {[0.001]^{* * *}} \\ \text { State Located } & -0.014 & -0.025 & -0.027 \\ & {[0.487]} & {[0.247]} & {[0.234]} \\ \text { CONTROLS } & \text { YES } & \text { YES } & \text { YES } \\ \text { Industry/Year } & \text { YES } & \text { YES } & \text { YES } \\ \mathrm{N} & 19,901 & 18,935 & 18,169 \\ \mathrm{R}^{2} & 12 \% & 11 \% & 11 \%\end{array}$

Panel B.

Dependent Variable

Takeover Index $t+1 \quad$ Takeover Index $t+1 \quad$ Takeover Index $t+2$

Restrictive State Subsample

Sample

$\begin{array}{lll}\log (\text { Litigation }) & 0.293 & 0.350 \\ & {[0.001]^{* * *}} & {[0.001]^{* * *}}\end{array}$

$\log ($ Litigation $)$

YES
YES
YES
NO
18,935
$30 \%$

0.038

$[0.001] * * *$

YES

$\mathrm{NO}$

YES

YES

18,169

$26 \%$

Table 6 reports the multivariate regression results between employee lawsuits and Takeover Index controlling for firm-level variables. In Panel A, we run difference and difference test. From column (1) to column (3), our dependent variable is log transformation of total lawsuits. We use the same set of control variables but omit coefficients. In column (1), (2), and (3), we run industry and year fixed effects, but omit the coefficients. In Panel B, we perform different types of fixed effects. In column (1), we run state (firm's location) and year fixed effects. In column (2), we run industry-state-year fixed effects. In column (3), we run industry and year fixed effects. Detailed definitions of variables are reported in the appendix. *, **, and *** indicate statistical significance at the $10 \%, 5 \%$, and $1 \%$ levels, respectively

In Panel B of Table 6, we include unique state fixed effects. Many states may have litigation that increases or decreases a firm's likelihood of being involved in employee ligation. For example, New Mexico (66\%), Washington, 
D.C. (65\%), Nevada (47\%), Alabama (41\%) and California (40\%) are the top states for employee lawsuits. At least ten employers face a much higher risk of being sued by their employees. To eliminate any unobserved state heterogeneity, we include state (location) and year fixed effects, as well as state-yearindustry fixed effects. In column (1) we show that a higher number of ligation still is associated with a higher likelihood of a takeover. In column (2) we included industry effects as well, all coefficients and effects remain consistent. Lastly, we define a "Restrictive State" as when a firm is located in a state that has passed restrictive takeover provisions (Francis et al. 2010). Column (3) shows that if a firm is incorporated in a state with restrictive antitakeover rules, it is likely to have a substantially higher number of lawsuits compared to firms that are located in less restrictive states. We confirm our findings by running year-state (location)-industry fixed effects.

In Table 7, we consider the issue of reverse causality. Although we perform state and year, industry and year fixed effects with a set of control variables; it is possible that employee lawsuits can occur at the state of incorporation and can be independent of the state-level adopted antitakeover measures. To eliminate that concern, we first test the timing of antitakeover acts. Pass Year $(-1),(-2)$, and $(+1)$ are dummy variables that equal one if the firm is incorporated in a state that passed an antitakeover law. In column (1), we run OLS regression where our dependent variable is the log transformation of the total number of litigations. In column (2), we run a logistic regression and our dependent variable is lawsuit, which is equal to one if the firm is facing at least one employee lawsuit, and zero otherwise. Our results, presented in Table 7, show that the number of lawsuits, as well as the probability of lawsuits, increased following the passage of the antitakeover law. Pass Year $(+1)$ is insignificant, which indicates that our results may not suffer from reverse causality.

In the next set of tests, we run an instrumental variable approach to confirm our early findings. Our main regressions treat the takeover index that measures managerial entrenchment as an exogenous variable. However, the takeover index may be endogenous due to some omitted variables which would affect both employee lawsuits and managerial entrenchment. To eliminate that concern, we first run a two-stage IV GMM regression, which treats the takeover index as an endogenous variable. The instrumental variable approach depends on both inclusion and exclusion criteria. It requires that our results must be a good predictor of the takeover index, but they must be not related to employee lawsuits or any types of employee relations. It is hard to find such instruments, as almost every firm-level variable can affect both managerial entrenchment and employee disputes. Therefore, we follow the previous literature of Sheikh (2018) who examines the relationship between antitakeover provisions and corporate social responsibility (CSR) dimensions.

Following Sheikh (2018), our first instrument is the industry-adjusted takeover index (based on the Fama and French 48 industry classification). John and Litov (2010) and Sheikh (2018) use the industry average governance index (GIndex) to predict G-index to examine the relationship between managerial entrenchment and firm value. For our second instrument, we again follow 
Table 7 Anti-takeover protection and employee lawsuits: Timing

Panel A.

Dependent Variable

Log(Litigation) $\quad$ Prob = Litigation

Sample

$\begin{array}{lll} & (1) & (2) \\ \text { Pass Year (-2) } & 0.064 & 0.112 \\ & {[0.001]^{* * *}} & {[0.001]^{* * * *}} \\ \text { Pass Year (-1) } & 0.029 & 0.445 \\ & {[0.033]^{* *}} & {[0.061]^{* *}} \\ \text { Pass Year (0) } & 0.040 & 0.221 \\ & {[0.032]^{* *}} & {[0.001]^{* * *}} \\ \text { Pass Year }(+1) & 0.028 & -0.887 \\ & {[0.334]} & {[0.933]} \\ \text { CONTROLS } & \text { YES } & \text { YES } \\ \text { Industry/Year } & \text { YES } & \text { YES } \\ \mathrm{N} & 18,169 & 18,169 \\ \mathrm{R}^{2} & 11 \% & 13 \%\end{array}$

Table 7 reports the multivariate regression results between the year of takeover defense pass in firm's incorporation state and employee lawsuits while controlling for firm-level variables. From column (1), our dependent variable is log transformation of total lawsuits. We run OLS regression. In column (2), our dependent variable is lawsuit and is a binary variable equal to one if the firm is facing an employee lawsuit, and zero otherwise. We run logistic regression. We use the same set of control variables but omit coefficients. We run industry and year fixed effects, but omit the coefficients. Detailed definitions of variables are reported in the appendix. $*, * *$, and $* * *$ indicate statistical significance at the $10 \%, 5 \%$, and $1 \%$ levels, respectively

Sheikh (2018), who uses average CEO tenure of peers in the same industry (Fama and French 48 industry classification) as an instrument. Our final instrument is industry average volatility, which is the median annualized volatility of daily stock returns (based on Fama and French 48 industry classification) and which can be an important determinant of the takeover index and only indirectly affect employee lawsuits.

Panel A of Table 8 shows first and second stage results from the IV GMM estimation. In the first stage, we regress firms' susceptibility to hostile takeover on instruments and other control variables. In the second stage, we use the predicted takeover index to estimate the number of employee lawsuits. Results from first stage regressions document significant coefficients for our instruments, which indicates the predictive power of the takeover index. Average CEO tenure and average takeover index increase firms' susceptibility to hostile takeover. On the other hand, average industry volatility lowers the takeover index. We also report F-test and Sargan scores in Panel A. Our F-test results show our instruments are valid, and the Sargan test documents that we can reject the null hypothesis that the instruments are weak. 
Table 8 Anti-takeover protection and employee lawsuits: Endogeneity concerns

Panel A.

Dependent Variable

IV GMM

Log(Litigation)

Takeover Index

Sample

Predicted Litigation

Instruments

CEO Political Ideology

0.673

$[0.001]^{* * * *}$

Local Election Result

0.199

$[0.021]^{* *}$

CONTROLS

YES

YES

Industry/Year

YES

YES

F-test

21.667

0.000

Sargan (score) chi2(2)

23.992

$(p=0.0000)$

N

18,169

18,169

$\mathrm{R}^{2}$

$15 \%$

$15 \%$

Panel B.

Dependent Variable

Heckman Two Stage

Home State

Takeover Index

Sample

$\log ($ Litigation $)$

0.664

0.112

$[0.001]^{* * * *}$

$[0.044]^{* *}$

0.733

[0.112]

CONTROLS

YES

YES

Industry/Year

YES

YES

$\mathrm{N}$

18,169

18,169

$\mathrm{R}^{2}$

$12 \%$

$12 \%$

Table 8 reports the multivariate regression results between Takeover Index and employee lawsuits to eliminate endogeneity concerns. In Panel A, we run 2-stage IV GMM regression. In column (1), we predict the Takeover Index. In column (2), we use predicted Takeover Index where our dependent variable is the log transformation of employee lawsuits. In Panel B, we run Heckman Two Stage regression to obtain inverse Mills Ratio in the first stage. In column (1), our dependent variable is Home state which is equal to one if the firm's home state equals its state of incorporation and zero otherwise. We run probit regression. In column (2), our dependent variable is log transformation of total lawsuits. We use the same set of control variables but omit coefficients. We run industry and year fixed effects, but omit the coefficients. Detailed definitions of variables are reported in the appendix. $*, * *$, and $* * *$ indicate statistical significance at the $10 \%, 5 \%$, and $1 \%$ levels, respectively

In Panel B of Table 8, we perform a Heckman two-stage correction, following Francis et al. (2010), who examine antitakeover provisions and bond yields. In the first stage, we estimate a Probit model if a firm chooses between 
incorporating in its home state or away from its headquarters. The dependent variable is Home State, which is equal to one if the firm's home state equals its state of incorporation and zero otherwise. We obtain the inverse of the Mills ratio from the first stage and control for it in our main regression in the second stage. We find that the inverse of Mills ratio from the first-stage Probit regression is not significant, which may eliminate the selection bias. Our results suggests that the firm's state of incorporation decision is not endogenous with the number of lawsuits it faces.

In the last set of tests, we perform matched sample analysis. We create three sets of matched samples. First, we match firms (in the same industry and year) based on total assets and book-to-market ratio. We match each firm that has faced an employee lawsuit to a firm that has not faced any litigation, based on size (total assets) and book-to-market ratio. In addition, we also match each lawsuit firm to a non-lawsuit firm by the number of employees and market-tobook ratios. We believe this is important since firms can be similar in size (total assets) but differ in the number of employees. To eliminate that possibility, we repeat our test, using the number of employees. Finally, we match our firms based on total sales and book-to-market ratio.

Table 9 presents the matched sample results from our study. In Panel A, we find that the number of employee litigations is positively and significantly related to the likelihood of takeover as measured by the takeover index. We confirm our results in panel data with matched samples as well as cross-sectional (one-to-one) matched samples. In Panels $\mathrm{B}$ and $\mathrm{C}$ we match our sample based on Book-to-Market and the total number of employees as well as Book-to-Market and sales. We document that the number of litigations increases a firms' susceptibility to a hostile takeover. Our results remain consistent across the matched values. Overall, our findings from Table 9 document that employee litigations increase a firms takeover index. The results of Table 9 confirm the baseline results of the study showing that costs from litigation can harm a firm and make it a takeover target.

\section{Conclusion}

This study empirically examines the relationship between employee treatment and managerial entrenchment. Our study is the first to document the impact of antitakeover provisions on employee lawsuits. We utilize data from employee litigations between 2000 and 2014 and document that the number of employee litigation a firm experience increases it suitability to takeover as measure by the takeover index of Cain et al. (2017). We supplement our findings by showing that when takeover protections pass, firms' on average have more employee litigations. Therefore, greater takeover protection leads to reduced corporate attention to employees. Our results suggest that when managers become protected from hostile takeovers, they may neglect the safety or security of their employees. The cases employed in this study are centered on discrimination or improper wage disputes. 
Table 9 Anti-takeover protection and employee lawsuits: Matched samples

Dependent Variable

$\log ($ Litigation $)$

CONTROLS

Industry/Year

$\mathrm{N}$

$\mathrm{R}^{2}$

Panel B.

Sample

$\log ($ Litigation $)$

CONTROLS

Industry/Year

$\mathrm{N}$

$\mathrm{R}^{2}$

Panel C.

Sample

Log(Litigation)

CONTROLS

Industry/Year

$\mathrm{N}$

$\mathrm{R}^{2}$

Matched: BtM \& Num. Empl.

0.773

$[0.021]^{* *}$

YES

YES

16,884

$31 \%$

Matched: BtM \& Sales

0.445

$[0.001]^{* * *}$

YES

YES

16,884

$25 \%$
Takeover Indext+1

Panel

Matched: BtM \& Total Asset

0.688

$$
[0.001]^{* * *}
$$

YES

YES

16,884

$34 \%$

Takeover Index t+1

Cross-Sectional

$[0.044]^{* * *}$

YES

YES

8,790

$36 \%$

0.255

$[0.001]^{* * * *}$

YES

YES

8,790

$35 \%$

0.135

$[0.001]^{* * * *}$

YES

YES

8,790

$27 \%$

Table 9 reports the multivariate regression results Takeover Index and employee lawsuits while controlling for firm-level variables. In Panel A, we match our sample by the total assets and book to market. In Panel B, we match our sample by number of employees and book to market. In Panel C, we match our sample by total sales and book-to-market ratios. We use the same set of control variables but omit coefficients. We run industry and year fixed effects, but omit the coefficients. Detailed definitions of variables are reported in the appendix. $* * *$, and $* * *$ indicate statistical significance at the $10 \%, 5 \%$, and $1 \%$ levels, respectively

Funding This research did not receive any specific grant from funding agencies in the public, commercial, or not-for-profit sectors.

\section{Compliance with ethical standards}

Conflict of interest The author declares that they have no conflict of interest. 


\section{Appendix 1}

\begin{tabular}{|c|c|}
\hline Variables & Definition \\
\hline \multicolumn{2}{|c|}{ Panel A. Employee Disputes } \\
\hline $\log ($ Litigation $)$ & Log transformation of total number of lawsuit \\
\hline Lawsuit & Binary variable and equal to one if firm is facing lawsuit, zero otherwise \\
\hline $\log ($ Discrimination $)$ & Log transformation of total number of discrimination \\
\hline Log(Litigation Cost) & Total amount of settlements, attorney fees, and other legal fees \\
\hline Log(Disputes) & $\begin{array}{l}\text { Log transformation of employee disputes including Occupational Safety and } \\
\text { Health Administration inspections, total number of concluded Wage and } \\
\text { Hour Division compliance actions, civil penalty from Wage and Hour } \\
\text { Division compliance actions. }\end{array}$ \\
\hline Days & Lawsuit duration: Case closure date minus case opening date \\
\hline
\end{tabular}

Source

Panel B. Control Variables

Takeover Index $\quad$ Firms' susceptibility to hostile takeover. Passage of 12 different types of state takeover laws, one federal statue, and three state standards of review

NLRB

NLRB

S\&P Capital IQ

S\&P Capital IQ

Dept. of. Labor

NLRB

State Located

Binary variable and equal to one if the firm is incorporated in any of the states passed antitakeover law based on Cain et al. (2017)

Post Year

Binary variable and equal to one for years after takeover defense is passed, zero otherwise

Restrictive State

Binary variable and equal to one if firm is located in a state that has passed restrictive takeover provisions (Francis et al. 2010)

Avg. Tenure

Median tenure of all CEOs in the same Fama and French (1997) classification of 48 industry groups

Avg. Takeover Index

Avg. Industry Volatility

$\log$ (Asset)

Log(Num. Emp)

ROA

Book-to-Market

Book Leverage

Median Takeover Index in the same Fama and French (1997) classification of 48 industry groups

Median annualized volatility of stock returns in the same Fama and French (1997) classification of 48 industry groups

Log transformation of total assets

Log transformation of total num. Employee

Earnings before interests and taxes divided by assets

Firm's book-to-market ratio.

Log(CEO Age)

Debt in current liabilities plus long-term debt divided by assets

$\log (\mathrm{CEO}$ Compensation)

Log(Firm Age)

Log transformation of CEO age

Log transformation of CEO compensation

Log transformation of firm age

http://pages.uoregon. edu/smckeon/

S\&P Capital IQ

S\&P Capital IQ

S\&P Capital IQ

S\&P Capital IQ

S\&P Capital IQ

S\&P Capital IQ

S\&P Capital IQ

S\&P Capital IQ

S\&P Capital IQ

S\&P Capital IQ

S\&P Capital IQ

S\&P Capital IQ

S\&P Capital IQ

S\&P Capital IQ

Capital Liquidity

spread between the commercial and industrial (C\&I) loan rate and the federal funds rate

Cash Holding

CAPEX

Total cash normalized by total assets

Capital Expenditure normalized by total asset

http://pages.uoregon edu/smckeon/

S\&P Capital IQ

Industry concentration by summing the squared market sharesof the firms in the industry.

Pension Expenses

Pension expense divided by the product of beginning share priceand common shares outstanding.

Personal Intentisy

Property, Plant, Equip.

Number of employee normalized by total asset.

S\&P Capital IQ

S\&P Capital IQ

S\&P Capital IQ

Natural logarithm of net property, plant and equipment divided by the number of employees.

State Unionization

$\%$ Industry

unionization

Percentage of union membership at firm's headquarter state.

S\&P Capital IQ

Percentage of union membership at industry level

www.unionstats.com

www.unionstats.com

Union membership growth at industry level

www.unionstats.com Growth 


\section{References}

Al Mamun, M, Balachandran B, Duong HN (2017) Powerful CEOs and stock Price crash risk. Working Paper. SSRN

Armstrong CS, Balakrishnan K, Cohen D (2012) Corporate governance and the information environment: evidence from state antitakeover laws. J Account Econ 53(1-2):185-204

Atanassov J, Liu X (2014) Corporate income taxes, financial constraints and innovation. Unpublished working paper, University of Nebraska and University of Oregon

Bae KH, Kang JK, Wang J (2011) Employee treatment and firm leverage: A test of the stakeholder theory of capital structure. J. Financ. Econ 100(1):130-153

Barnea A, Rubin A (2010) Corporate social responsibility as a conflict between shareholders. J Bus Ethics 97(1):71-86

Bebchuk LA, Cohen A (2005) The costs of entrenched boards. J Financ Econ 78(2):409-433

Bebchuk L, Cohen A, Ferrell A (2008) What matters in corporate governance? Rev Financ Stud 22(2):783827

Bertrand M, Mullainathan S (2003) Enjoying the quiet life? Corporate governance and managerial preferences. J Polit Econ 111(5):1043-1075

Bhargava R, Faircloth S, Zeng H (2017) Takeover protection and stock price crash risk: evidence from state antitakeover laws. J Bus Res 70:177-184

Bhojraj S, Sengupta P, Zhang S (2017) Takeover defenses: entrenchment and efficiency. J Account Econ 63(1):142-160

Cain MD, McKeon SB, Solomon SD (2017) Do takeover laws matter? Evidence from five decades of hostile takeovers. J Financ Econ 124(3):464-485

Cen L, Dasgupta S, Sen R (2015) Discipline or disruption? Stakeholder relationships and the effect of takeover threat. Manag Sci 62(10):2820-2841

Chang X, Zhang HF (2015) Managerial entrenchment and firm value: a dynamic perspective. J Financ Quant Anal 50(5):1083-1103

Chemmanur T, Tian X (2017) Do anti-takeover provisions spur corporate innovation? A regression discontinuity analysis

Chen T, Lin C, Shao X (2016) Globalization and US corporate tax policies: evidence from import competition

Cheng S, Nagar V, Rajan MV (2004) Identifying control motives in managerial ownership: evidence from antitakeover legislation. Rev Financ Stud 18(2):637-672

Chintrakarn P, Jiraporn P, Kim JC, Kim YS (2016) The effect of corporate governance on corporate social responsibility. Asia Pac J Financ Stud 45(1):102-123

Coff RW (1997) Human assets and management dilemmas: coping with hazards on the road to resource-based theory. Acad Manag Rev 22(2):374 402

Cohen A, Wang CC (2013) How do staggered boards affect shareholder value? Evidence from a natural experiment. J Financ Econ 110(3):627-641

Collins D, Huang H (2011) Management entrenchment and the cost of equity capital. J Bus Res 64(4):356362

Cremers M, Ferrell A (2009) Thirty years of corporate governance: firm valuation \& stock returns. Revise and resubmit at Journal of Finance

Cremers KJ, Nair VB, Peyer U (2008) Takeover defenses and competition: the role of stakeholders. J Empir Leg Stud 5(4):791-818

Daines R (2001) Does Delaware law improve firm value? J Financ Econ 62(3):525-558

DeAngelo H, Rice EM (1983) Antitakeover charter amendments and stockholder wealth. J Financ Econ 11(14):329-359

Duong HN, Nguyen JH, Rhee SG (2017) Economic policy uncertainty and corporate cash holdings, Economic Policy Uncertainty and Corporate Cash Holdings

Duru A, Wang D, Zhao Y (2013) Staggered boards, corporate opacity and firm value. J Bank Financ 37(2): $341-360$

Edmans A (2011) Does the stock market fully value intangibles? Employee satisfaction and equity prices. J Financ Econ 101(3):621-640

Fama EF, French KR (1997) Industry costs of equity. J Financ Econ 43(2):153-193

Francis BB, Hasan I, John K, Waisman M (2010) The effect of state antitakeover laws on the firm's bondholders. J Financ Econ 96(1):127-154

Freeman RE (1983) Strategic management: a stakeholder approach. Adv Strateg Manag 1(1):31-60 
Freidman M (1970) September; 13. The social responsibility of business is to increase its profits. New York times magazine

Garvey GT, Hanka G (1999) Capital structure and corporate control: the effect of antitakeover statutes on firm leverage. J Financ 54(2):519-546

Gompers P, Ishii J, Metrick A (2003) Corporate governance and equity prices. Q J Econ 118(1):107-156

Hackl JW, Testani RA (1988) Second generation state takeover statutes and shareholder wealth: an empirical study. Yale LJ 97(6):9

Jensen MC (2002) Value maximization, stakeholder theory, and the corporate objective function. Bus Ethics Q 12:235-256

Jensen MC, Meckling WH (1976) Theory of the firm: managerial behavior, agency costs and ownership structure. J Financ Econ 3(4):305-360

Jensen MC, Ruback RS (1983) The market for corporate control: the scientific evidence. J Financ Econ 11(14):5-50

John K, Litov L (2010) Managerial entrenchment and capital structure: new evidence. J Empir Leg Stud 7(4): 693-742

Johnson MS, Rao RP (1997) The impact of antitakeover amendments on corporate financial performance. Financ Rev 32(4):659-690

Kacperczyk A (2009) With greater power comes greater responsibility? Takeover protection and corporate attention to stakeholders. Strateg Manag J 30(3):261-285

Karpoff JM, Malatesta PH (1989) The wealth effects of second-generation state takeover legislation. J Financ Econ 25(2):291-322

Liu X (2016) Corruption culture and corporate misconduct. J Financ Econ 122(2):307-327

Long WF, Ravenscraft DJ (1993) LBOs, debt and R\&D intensity. Strateg Manag J 14(S1):119-135

Mahoney JM, Mahoney JT (1993) An empirical investigation of the effect of corporate charter antitakeover amendments on stockholder wealth. Strateg Manag J 14(1):17-31

Mahoney JM, Sundaramurthy C, Mahoney JT (1997) Board structure, antitakeover provisions, and stockholder wealth. Strateg Manag J:231-245

Manne HG (1965) Mergers and the market for corporate control. J Polit Econ 73(2):110-120

Manso G (2011) Motivating innovation. J Financ 66(5):1823-1860

Moore JA, Suh S, Werner EM (2017) Dual entrenchment and tax management: classified boards and family firms. J Bus Res 79:161-172

Pound J (1987) The effects of antitakeover amendments on takeover activity: some direct evidence. J Law Econ 30(2):353-367

Pugh WN, Jahera JS (1990) State antitakeover legislation and shareholder wealth. J Financ Res 13(3):221-231

Schmid, M., Limbach, P., \& Scholz, M. (2016). All good things come to an end: CEO tenure and firm value

Sheikh S. (2018). Is corporate social responsibility a value-increasing investment? Evidence from antitakeover provisions. Glob Financ J 38:1-12

Sheikhbahaei A, Balachandran B, Di Iorio A, Duong H (2018) Corporate Governance Strength and Cost of SEOs. European Finance Association Meeting, Milan

Shleifer A, Summers LH (1988) Breach of trust in hostile takeovers. In: Corporate takeovers: causes and consequences. University of Chicago Press, pp 33-68

Stein JC (1988) Takeover threats and managerial myopia. J Polit Econ 96(1):61-80

Surroca, J., \& Tribó, J. A. (2009). Is managerial entrenchment always bad?: a CSR approach

Szewczyk SH, Tsetsekos GP (1992) State intervention in the market for corporate control: the case of Pennsylvania senate bill 1310. J Financ Econ 31(1):3-23

Zhao Y, Allen A, Hasan I (2013) State antitakeover laws and voluntary disclosure. J Financ Quant Anal 48(2): $637-668$

Publisher's note Springer Nature remains neutral with regard to jurisdictional claims in published maps and institutional affiliations. 